\title{
Self-Calibrating Bipartite Fluorescent Sensor for Nitroreductase Activity and Its Application to Cancer and Hypoxic Cells
}

\author{
Shin A Yoon, ${ }^{\mathrm{a}}$ Jieun Chun, ${ }^{\mathrm{b}}$ Chulhun Kang*b and Min Hee Lee*a \\ ${ }^{a}$ Department of Chemistry, Sookmyung Women's University, Seoul 04310, Korea \\ ${ }^{b}$ The School of East-West Medical Science, Kyung Hee University, Yongin 17104, Korea \\ *Corresponding authors: minheelee@ sookmyung.ac.kr (M. H. Lee), kangch@ khu.ac.kr (C. Kang)
}

\section{Contents}

1. Materials and instrumentation

2. UV/Vis absorption and fluorescence spectroscopic methods

3. Enzyme kinetics

4. Cell culture and confocal microscopic methods

5. MTT assay

6. Co-staining of probe and organelle trackers and confocal microscopic methods

7. CoCl2-induced hypoxic HeLa cells and inhibitory assay methods

8. Supplementary data

9. ${ }^{1} \mathrm{H},{ }^{13} \mathrm{C}$ NMR and HR-ESI-MS spectra

10. Reference 


\section{Materials and instrumentation}

All reagents, such as NADH and nitroreductase (NTR) from Escherichia coli, metals (chloride salts of $\mathrm{K}^{+}, \mathrm{Na}^{+}, \mathrm{Ag}^{+}, \mathrm{Mg}^{2+}, \mathrm{Ca}^{2+}, \mathrm{Cu}^{2+}, \mathrm{Zn}^{2+}, \mathrm{Fe}^{2+}, \mathrm{Fe}^{3+}, \mathrm{Ba}^{2+}, \mathrm{Cd}^{2+}, \mathrm{Pb}^{2+}, \mathrm{Hg}^{2+}, \mathrm{Ni}^{2+}, \mathrm{Co}^{2+}$, and $\mathrm{Cu}^{+}$ions), anions (tetrabutylammonium (TBA) salts of $\mathrm{H}_{2} \mathrm{PO}_{4}^{-}, \mathrm{HSO}_{4}^{-}, \mathrm{ClO}_{4}^{-}, \mathrm{AcO}^{-}, \mathrm{CN}^{-}, \mathrm{OH}^{-}, \mathrm{F}^{-}$ , $\mathrm{Cl}^{-}$, and $\mathrm{I}^{-}$ions), reactive oxygen species $\left(\mathrm{ClO}^{-}, \mathrm{H}_{2} \mathrm{O}_{2},{ }^{\circ} \mathrm{O}_{2}^{-},{ }^{\circ} \mathrm{OH}, \mathrm{t}-\mathrm{BuO}{ }^{\bullet}, \mathrm{t}-\mathrm{BuOOH}, \mathrm{NO}\right.$, and $\mathrm{ONOO}^{-}$), thiols (cysteine (Cys), homocysteine (Hcy), glutathione (GSH), and NaHS), bovine serum albumin (BSA), glucose, ascorbic acid, glycine, and other chemicals for synthesis, buffer solution were purchased from Aldrich (Aldrich, St. Louis, MO, USA), Alfa (Alfa, Heysham, LA3 2XY, United Kingdom) and TCI (TCI, Tokyo, Japan), and used as received. Stock solutions of metal chloride salts, thiols and reactive oxygen species (ROS) were prepared in deionized water. ROS stock solutions were prepared by using literature procedures. ${ }^{1}$ HPLC analyses were carried out on Shimadzu HPLC (Shimadzu LC 6AD) with a Thermo Scientific Acclain ${ }^{\mathrm{TM}} 120 \mathrm{C} 18$ (3 $\mu$,

$120 \AA, 2.1 \times 150 \mathrm{~mm}$ ) column. The flow rate was $0.5 \mathrm{~mL} / \mathrm{min}$. Buffer A (water with $0.1 \% \mathrm{v} / \mathrm{v}$ trifluoroacetic acid) and Buffer B (acetonitrile with $0.1 \% \mathrm{v} / \mathrm{v}$ trifluoroacetic acid) were used as the mobile phase. NMR spectra were recorded on Bruker $(500 \mathrm{MHz})$ instrument. HR-ESI-MS data were obtained using liquid chromatography mass spectrometer (LC/MS) at the Korea Basic Science Institute (Seoul).

\section{UV/Vis absorption and fluorescence spectroscopic methods}

All UV/Vis absorption and fluorescence spectra were recorded on UV-2600 (Shimadzu Corporation, Kyoto, Kyoto Prefecture, Japan) and RF-6000 (Shimadzu Corporation, Kyoto, Kyoto Prefecture, Japan) spectrophotometer, respectively. Stock solutions of compounds were prepared 
in DMSO (HPLC grade). All data were recorded in PBS solution (10 mM, pH 7.4) containing 10\% (v/v) of DMSO. Excitation wavelength was $430 \mathrm{~nm}$.

\section{Enzyme kinetics}

Fluorescence responses at $550 \mathrm{~nm}$ of probe $1(1-17 \mu \mathrm{M})$ to NTR $(0.1 \mu \mathrm{g} / \mathrm{mL})$ with NADH $(500$ $\mu \mathrm{M}$ ) was recorded for $5 \mathrm{~min}$ (time interval of $0.1 \mathrm{~s}$ ). All data were obtained in PBS solution (10 $\mathrm{mM}, \mathrm{pH} 7.4)$ containing $10 \%(\mathrm{v} / \mathrm{v})$ of DMSO at $37{ }^{\circ} \mathrm{C}$ with an excitation of $430 \mathrm{~nm}$. The fluorescence units were converted to concentration by relating the fluorescence signals derived from the known concentrations of compound 2. Plot of velocity $\left(\mu \mathrm{mol} \mathrm{min} \mathrm{m}^{-1} \mathrm{mgNR}^{-1}\right) v s$. [probe 1] $(\mu \mathrm{M})$ was used to obtain $\mathrm{K}_{\mathrm{m}}$ and $V_{\max }$ values from nonlinear least-squares analysis for MichaelisMenten kinetics (OriginPro 8.0). From this, $\mathrm{k}_{\mathrm{cat}}$ and $\mathrm{k}_{\mathrm{cat}} / \mathrm{K}_{\mathrm{m}}$ values were obtained.

\section{Cell culture and confocal microscopic methods}

A human cervical cancer cells (HeLa) were cultured in Dulbecco's modified Eagle's medium (DMEM) supplemented with $10 \%$ Gibco $^{\circledR}$ fetal bovine serum (FBS), and $100 \mathrm{U} / \mathrm{mL}$ penicillinstreptomycin. Adenocarcinoma human alveolar basal epithelial cells (A549) and human hepatocellular liver carcinoma cells (HepG2) were cultured Roswell Park Memorial Institute (RPMI) 1640 Medium supplemented with $10 \%$ FBS, and $100 \mathrm{U} / \mathrm{mL}$ penicillin-streptomycin. Mouse embryonic fibroblast cells (NIH-3T3) were cultured in DMEM supplemented with 10\% Gibco $^{\circledR}$ bovine calf serum (BCS), and $100 \mathrm{U} / \mathrm{mL}$ penicillin-streptomycin. At 2 days before the microscopic experiments, the cells were transferred on cover glass-bottom dish. The cells were seeded at $10^{5}$ per dish and maintained at $37^{\circ} \mathrm{C}$ in a humidified atmosphere consisting of $5 \%(\mathrm{v} / \mathrm{v})$ $\mathrm{CO}_{2}$ containing air. All cells were purchased from Korean Cell Line Bank (Seoul, South Korea). 
For cell culture media, DMEM, RPMI, FBS, trypsin $0.25 \%$-EDTA and penicillin-streptomycin were purchased from BIOWEST (Nuaillé-France). The clear and adhesion-typed confocal dishes $($ diameter $=35 \mathrm{~mm})$ were purchased from SPL (Phocheon-si, Korea).

\section{MTT assay}

Cell viability was assessed by MTT (3-(4,5-dimethylthiazol-2-yl)-2,5-diphenyltetrazolium bromide) assay. Cells at $1.5 \times 10^{4} / \mathrm{mL}$ were treated with different concentrations of probe $\mathbf{1}$ in 96 well plates for $24 \mathrm{~h}$ at $37^{\circ} \mathrm{C}$. Then, a solution of MTT in serum free media $(5 \mathrm{mg} / \mathrm{mL})$ was added to each well, which was then further incubated for $3 \mathrm{~h}$. The water-insoluble formazan was formed during the incubation, and then DMSO was added to each well. The amount of formazan was then measured by checking the absorbance at $540 \mathrm{~nm}$ using a Spectra Max i3x microplate reader (Molecular devices, San Jose, CA). MTT was purchased from Sigma-Aldrich (St. Louis, MO) and used as received without further purification.

\section{Co-staining of probe and organelle trackers and confocal microscopic methods}

Organelle tracking dyes for co-localization experiments were purchased from Invitrogen. HeLa cells were pretreated with ER-Red $(0.7 \mu \mathrm{M})$, Lyso-Red $(0.05 \mu \mathrm{M})$, or Mito-Red $(0.1 \mu \mathrm{M})$, respectively, in DMEM media for $15 \mathrm{~min}$ at $37^{\circ} \mathrm{C}$. The cells were subsequently incubated with probe $1(5 \mu \mathrm{M})$ in DMEM media for $20 \mathrm{~min}$ at $37^{\circ} \mathrm{C}$, and then washed with PBS. The excitation wavelength and filter set were $405 \mathrm{~nm}$ with a 505-600 nm band path (BP) and $555 \mathrm{~nm}$ with a 605$800 \mathrm{~nm} \mathrm{BP}$ for probe 1 and organelle trackers, respectively. Fluorescence images were obtained using Zeiss LSM-700 with 40x objective (1x and 1.5x zoom) (Carl Zeiss, Oberkochen, Germany). Image analysis was performed using ZEN software and autoQuant X3. 


\section{7. $\mathrm{CoCl}_{2}$-induced hypoxic HeLa cells and inhibitory assay methods}

Cobalt chloride hexahydrate $\left(\mathrm{CoCl}_{2}\right)$ and dicoumarol (Dic) were purchased from Sigma-Aldrich (St. Louis, MO) and used as received without further purification. Stock solution of $\mathrm{CoCl}_{2}$ and dicoumarol were prepared in deionized water. HeLa cells were pretreated with $\mathrm{CoCl}_{2}(50 \mu \mathrm{M})$ in DMEM media for $24 \mathrm{~h}$ at $37^{\circ} \mathrm{C}$. The cells were subsequently incubated with or without dicoumarol $(500 \mu \mathrm{M})$ for $4 \mathrm{~h}$ at $37^{\circ} \mathrm{C}$. Then, probe $1(0.5 \mu \mathrm{M})$ was added to each cell for $30 \mathrm{~min}$ at $37^{\circ} \mathrm{C}$. The excitation laser was $405 \mathrm{~nm}$ and emission filters were 420-475 nm BP and 505-600 nm BP for blue and green channels. Image analysis was performed using ZEN software and Image J software.

\section{Supplementary data}
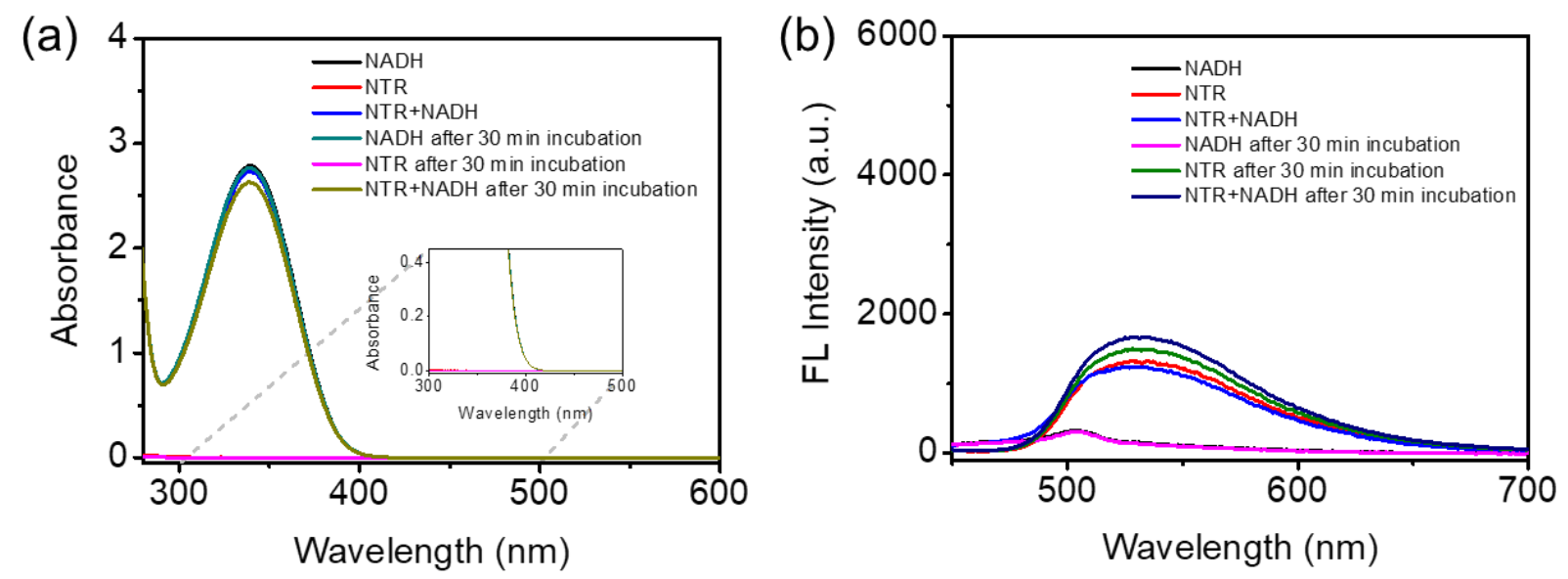

Figure S1. (a) UV/Vis absorption and (b) fluorescence spectra of NTR (5 $\mu \mathrm{g} / \mathrm{mL})$, NADH (500 $\mu \mathrm{M})$ and NTR/NADH, respectively. All data were obtained in PBS (10 mM, pH 7.4) solution containing $10 \%(\mathrm{v} / \mathrm{v})$ of DMSO using an excitation at $430 \mathrm{~nm}$ before and after 30 min incubation at $37^{\circ} \mathrm{C}$. 


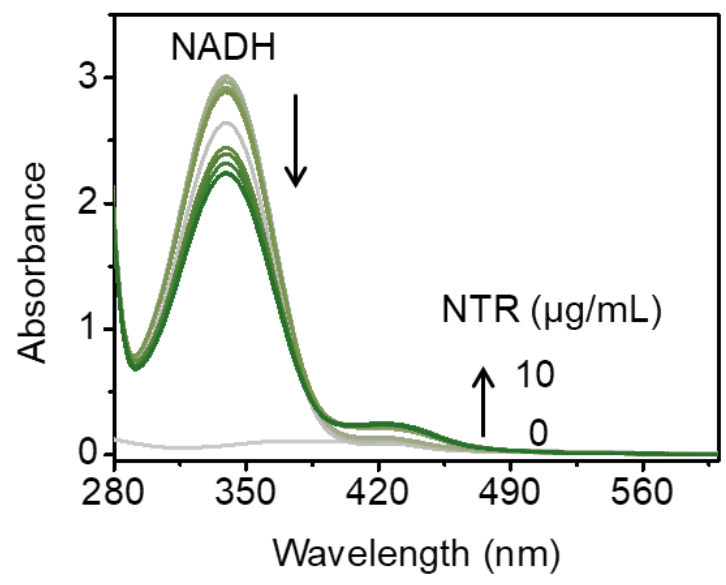

Figure S2. UV/Vis absorption of $1(10 \mu \mathrm{M})$ to different concentration of NTR $(0-10 \mu \mathrm{g} / \mathrm{mL})$ in presence of $\mathrm{NADH}(500 \mu \mathrm{M})$. All data were obtained in PBS (10 mM, pH 7.4) solution containing $10 \%(\mathrm{v} / \mathrm{v})$ of DMSO after $30 \mathrm{~min}$ incubation at $37{ }^{\circ} \mathrm{C}$ using an excitation at $430 \mathrm{~nm}$.

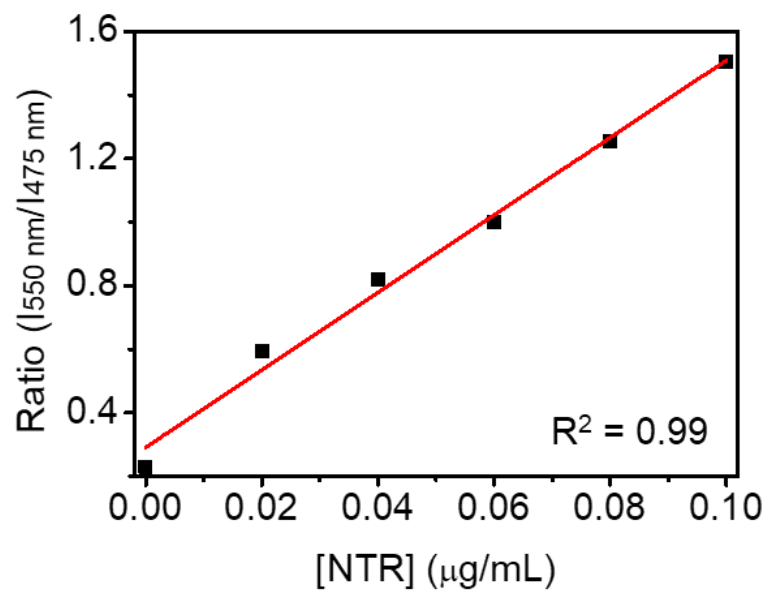

Figure S3. Plot of fluorescence intensity ratio $\left(\mathrm{I}_{550 \mathrm{~nm}} / \mathrm{I} 475 \mathrm{~nm}\right) v s$. [NTR] in the presence of NADH $(500 \mu \mathrm{M})$. All data were obtained in PBS $(10 \mathrm{mM}, \mathrm{pH} 7.4)$ solution containing $10 \%$ (v/v) of DMSO after $30 \mathrm{~min}$ incubation at $37^{\circ} \mathrm{C}$ using an excitation at $430 \mathrm{~nm}$. 


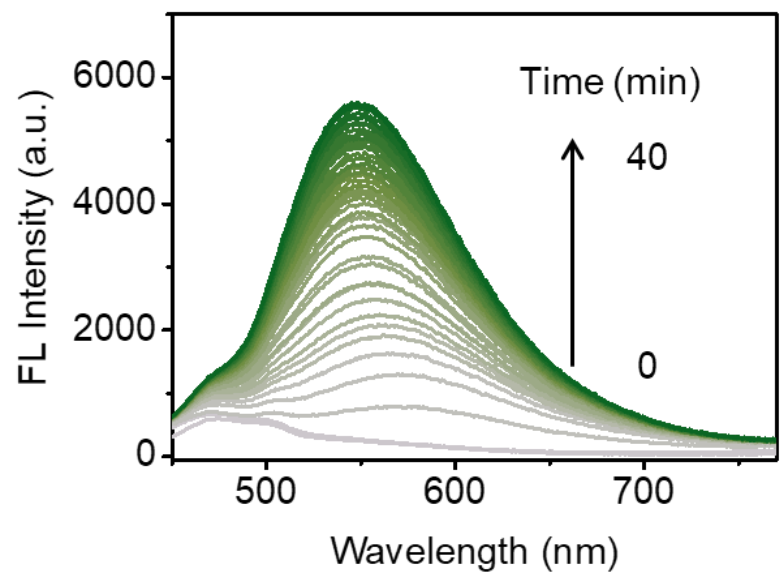

Figure S4. Time-dependent fluorescence increase of probe $1(10 \mu \mathrm{M})$ upon the addition of NTR $(5 \mu \mathrm{g} / \mathrm{mL})$ and NADH $(500 \mu \mathrm{M})$. All data were obtained in PBS (10 mM, pH 7.4) solution containing $10 \%(\mathrm{v} / \mathrm{v})$ of DMSO at $37^{\circ} \mathrm{C}$ using an excitation of $430 \mathrm{~nm}$.

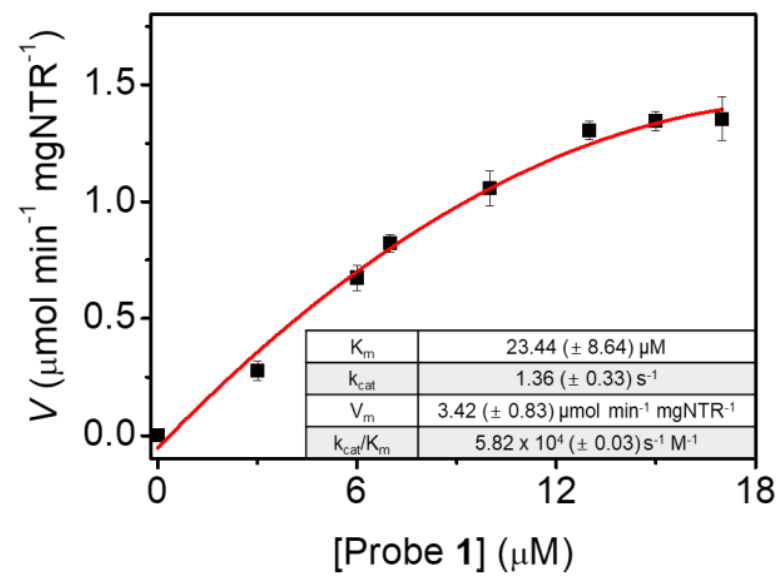

Figure S5. Enzyme kinetics of NTR $(0.1 \mu \mathrm{g} / \mathrm{mL})$ in the presence of NADH $(500 \mu \mathrm{M})$ with different concentration of probe $\mathbf{1}$ (mean \pm s.d., $\mathrm{n}=3$ ). All data were obtained in PBS (10 mM, $\mathrm{pH}$ 7.4) solution containing $10 \%(\mathrm{v} / \mathrm{v})$ of DMSO after $30 \mathrm{~min}$ incubation at $37^{\circ} \mathrm{C}$ using an excitation at $430 \mathrm{~nm}$. 


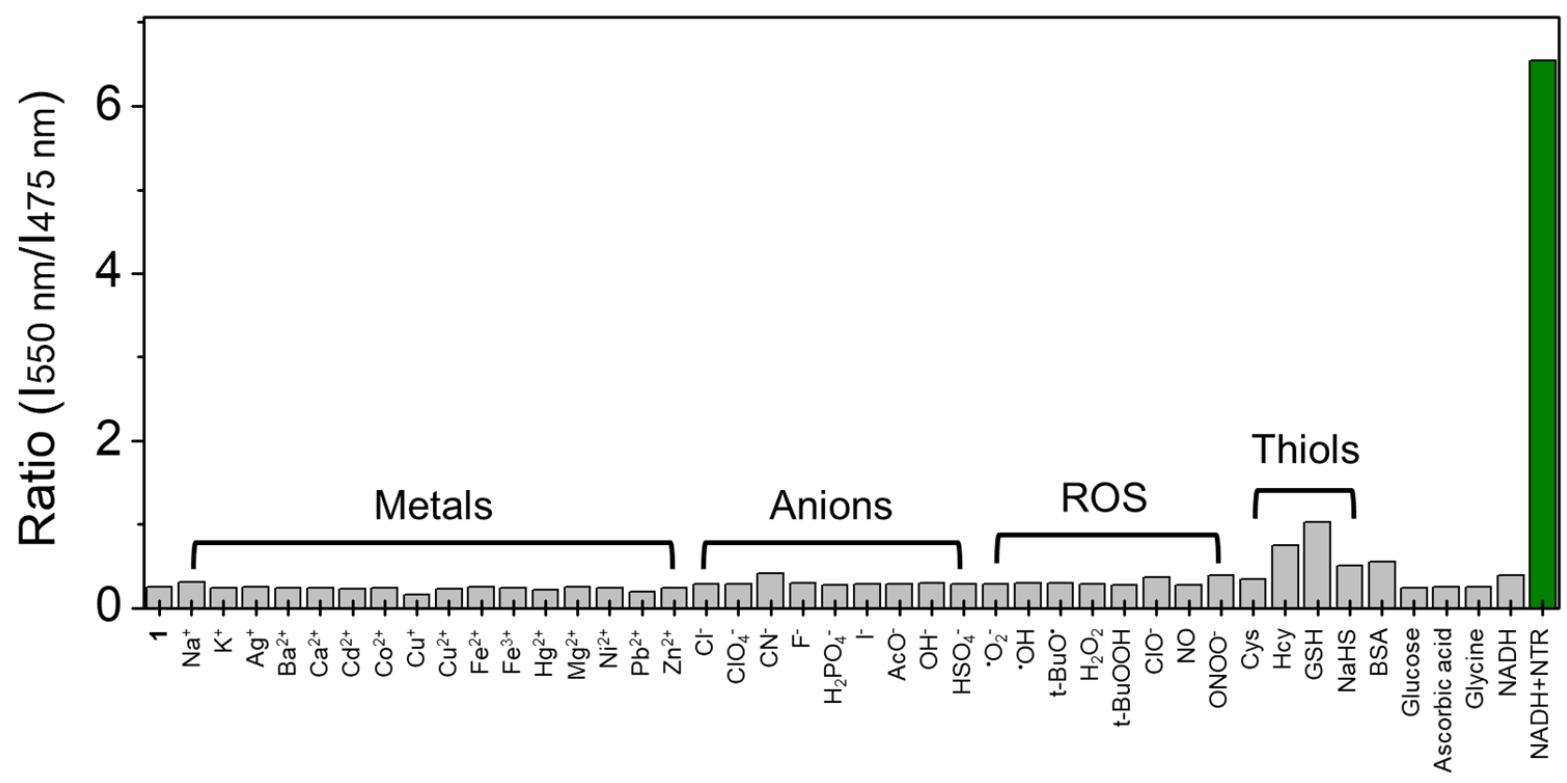

Figure S6. Fluorescence intensity ratio $\left(\mathrm{I}_{550} \mathrm{~nm} / \mathrm{I} 475 \mathrm{~nm}\right)$ of probe $\mathbf{1}(10 \mu \mathrm{M})$ in the presence of various analytes, such as NTR $(5 \mu \mathrm{g} / \mathrm{mL}) / \mathrm{NADH}(500 \mu \mathrm{M})$, metal ions (200 $\mu \mathrm{M}$, respectively),

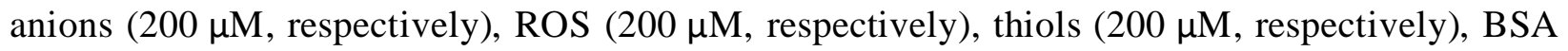
$(1 \mu \mathrm{g} / \mathrm{mL})$, glucose $(1 \mathrm{mM})$, ascorbic acid $(1 \mathrm{mM})$, and glycine $(200 \mu \mathrm{M})$. All data were obtained in PBS (10 mM, pH 7.4) solution containing $10 \%(\mathrm{v} / \mathrm{v})$ of DMSO after $30 \mathrm{~min}$ incubation at $37{ }^{\circ} \mathrm{C}$ using an excitation at $430 \mathrm{~nm}$. 


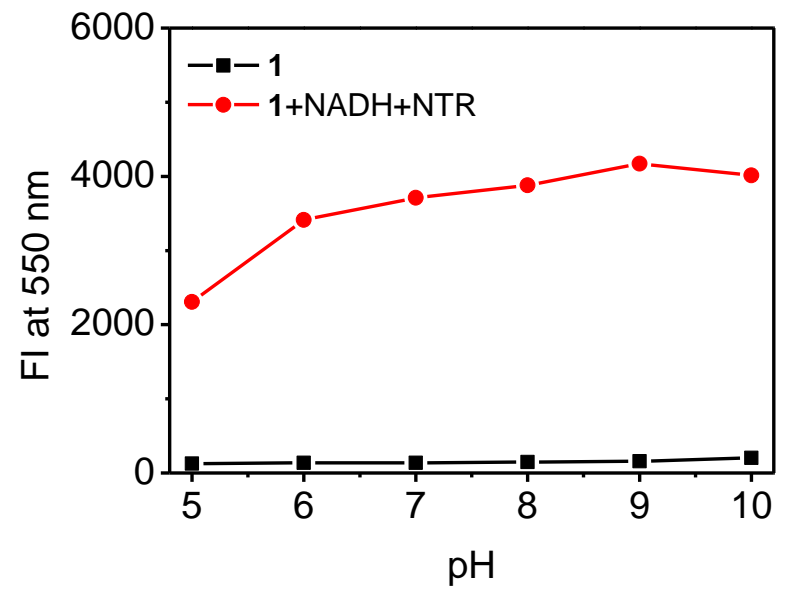

Figure S7. Fluorescence response of probe $1(10 \mu \mathrm{M})$ in the absence and presence of NTR (5 $\mu \mathrm{g} / \mathrm{mL})$ and $\mathrm{NADH}(500 \mu \mathrm{M})$ at different $\mathrm{pH}$ values. All data were recorded in different $\mathrm{pH}$ buffer solutions containing $10 \%(\mathrm{v} / \mathrm{v})$ of DMSO using an excitation at $430 \mathrm{~nm}$ after $30 \mathrm{~min}$ incubation at $37{ }^{\circ} \mathrm{C}$.

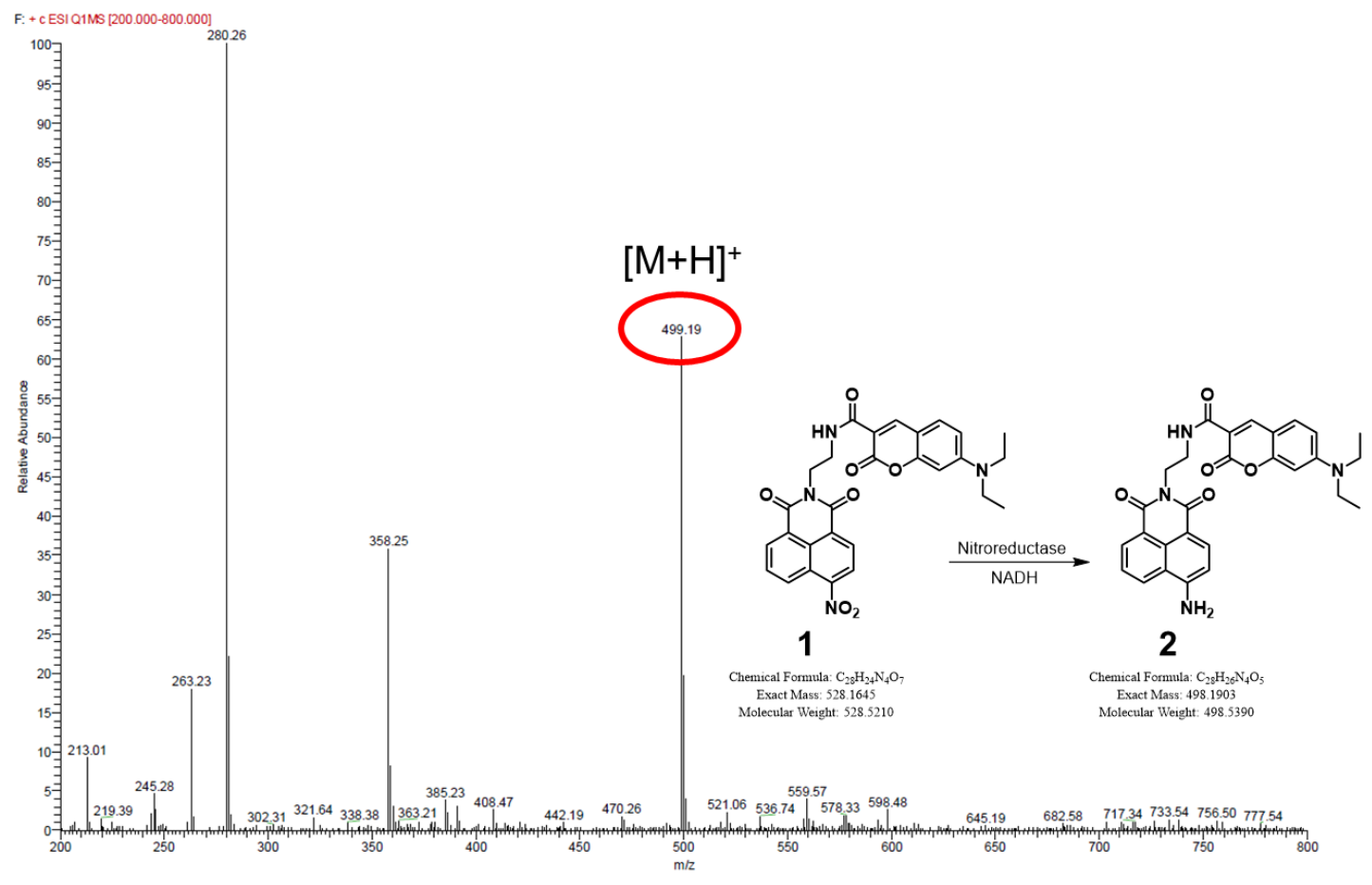

Figure S8. LC-ESI-MS spectrum of probe 1 after incubation with NTR and NADH in buffer solution (Retention time at $11.09 \mathrm{~min}$ ). 


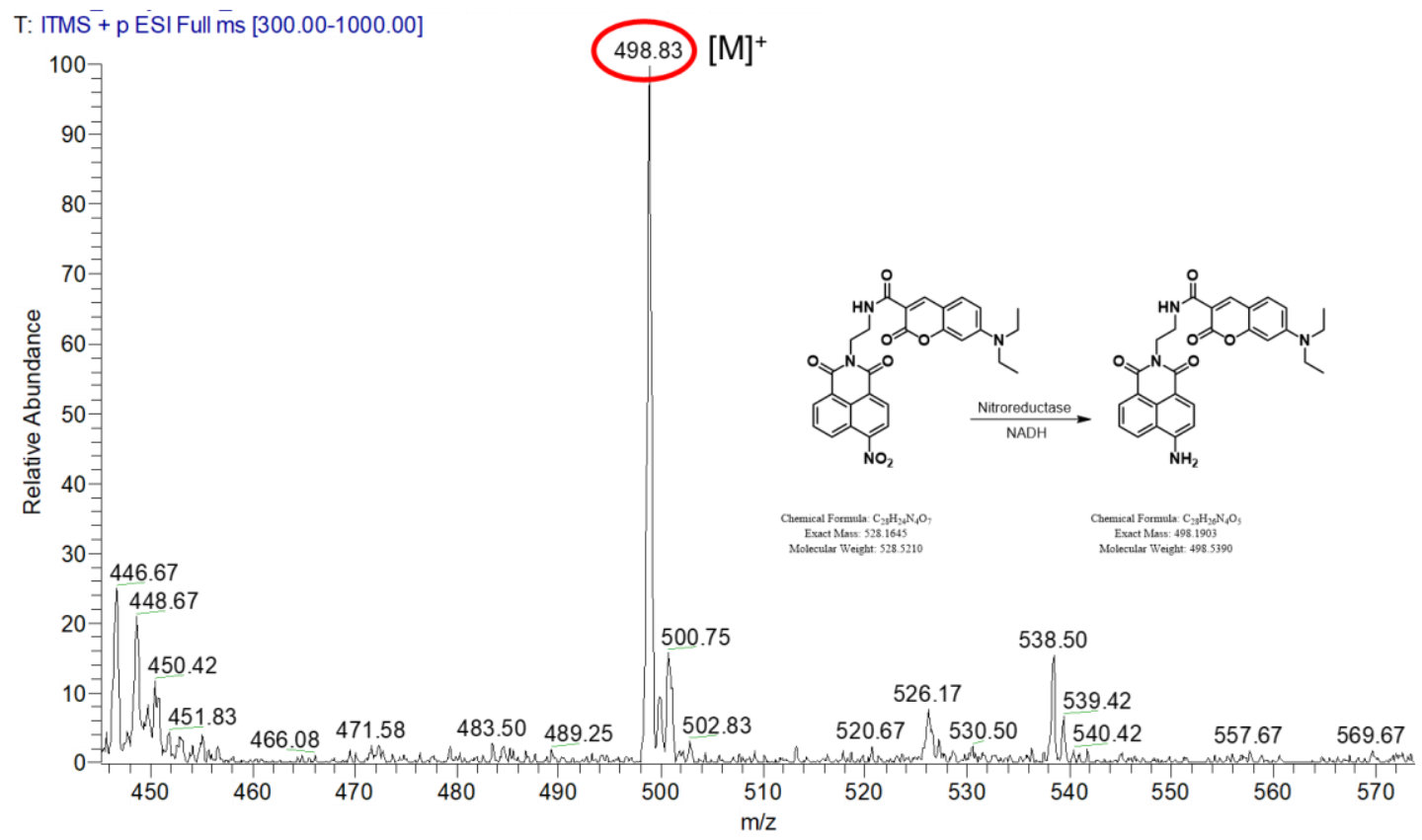

Figure S9. LC-ESI-MS spectrum of lysate of the probe 1-treated cells (Retention time at 11.09 $\min )$.

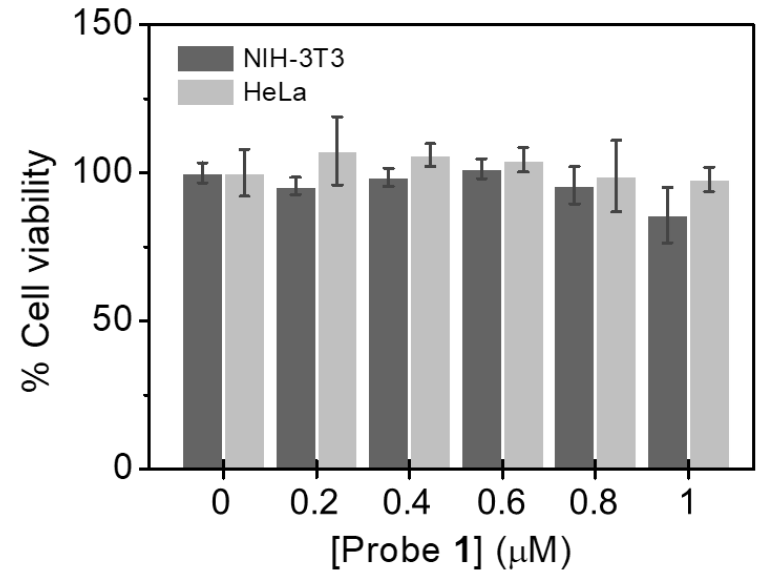

Figure S10. Cell viabilities of probe 1 for 24 h in NIH-3T3 and HeLa cells, respectively. Error bars indicate standard deviation $(\mathrm{SD}, \mathrm{n}=4)$. 

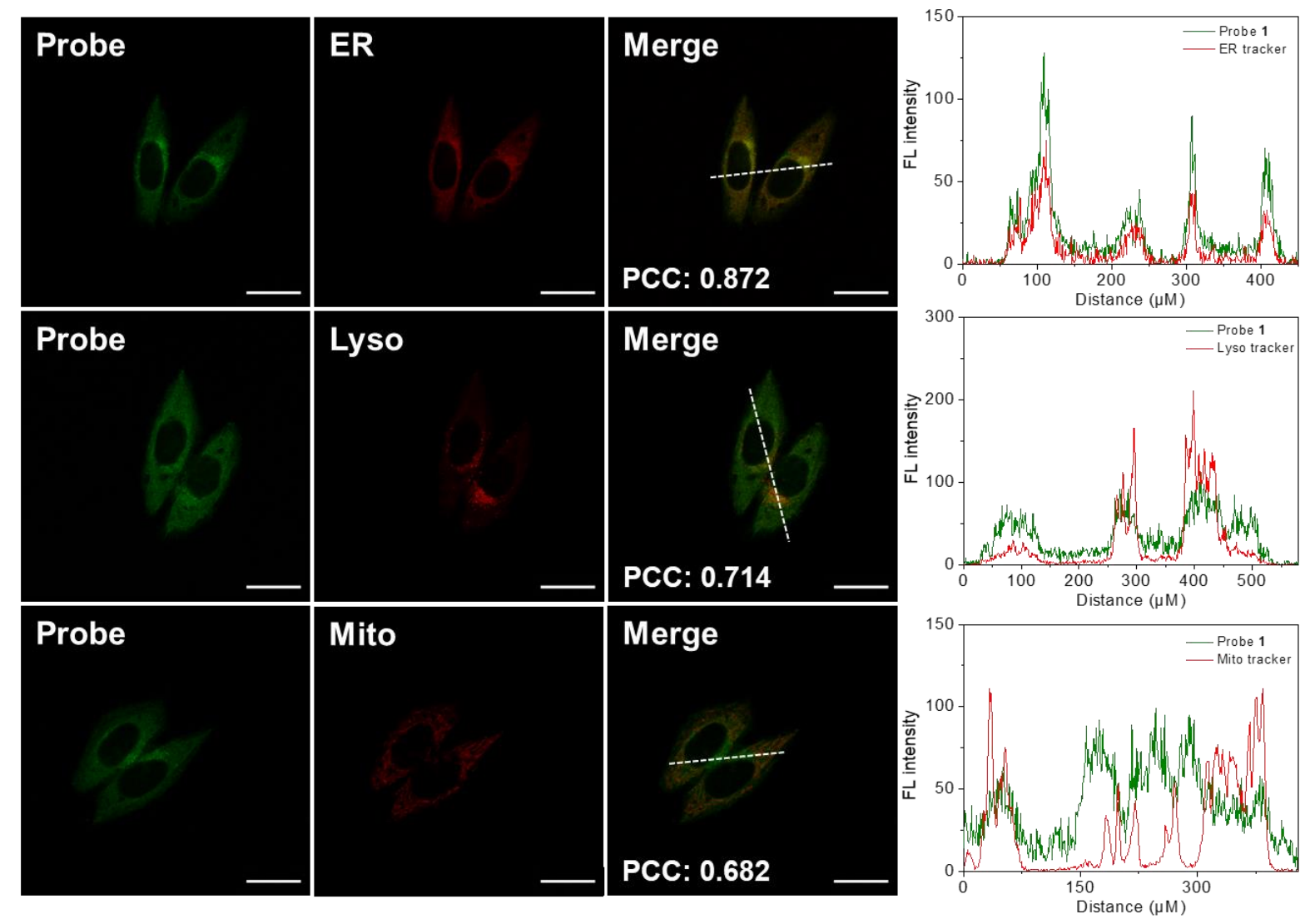

Figure S11. Co-staining of probe 1 and organelle trackers in HeLa cells. Cells were stained with probe $1(0.5 \mu \mathrm{M}, 30 \mathrm{~min})$ and Mito-Tracker (0.1 $\mu \mathrm{M}, 15 \mathrm{~min})$, Lyso-Tracker (0.05 $\mu \mathrm{M}, 15 \mathrm{~min})$, and ER-Tracker $(0.7 \mu \mathrm{M}, 15 \mathrm{~min})$. The PCC values indicating the colocalization between probe 1 and organelle trackers were obtained using autoQuant X3. Line profiles of fluorescence intensity of probe $\mathbf{1}$ and each organelle tracker were obtained by following the white line in the merged images. The excitation laser and filter sets were $405 \mathrm{~nm}$ with a 505-600 $\mathrm{nm}$ band path (BP) and $555 \mathrm{~nm}$ with a 605-800 $\mathrm{nm}$ BP for probe 1 (green channel) and organelle trackers (red channel), respectively. Scale bar: $20 \mu \mathrm{m}$. 
9. ${ }^{1} \mathrm{H},{ }^{13} \mathrm{C}$ NMR and HR-ESI-MS spectra

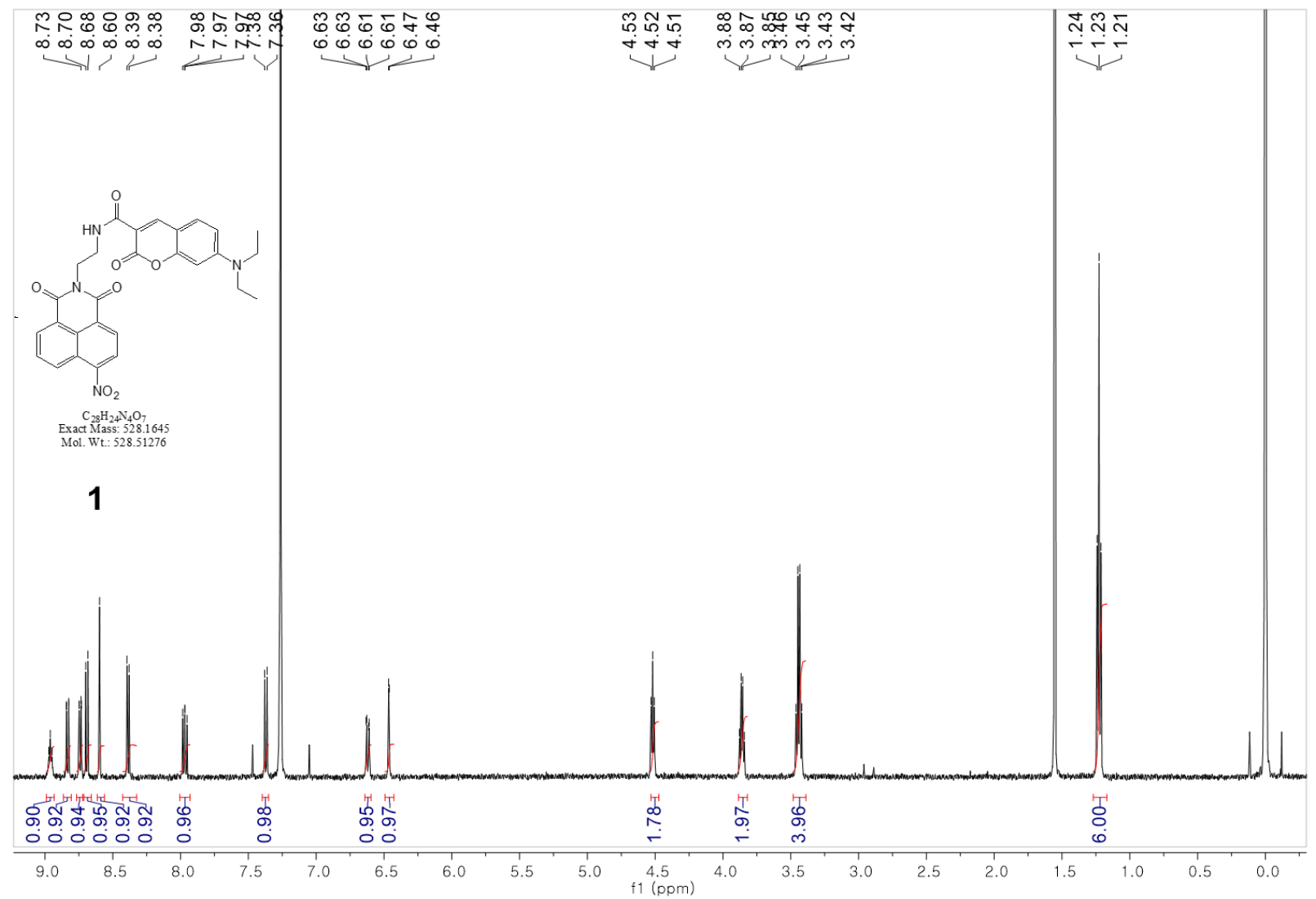

Figure S12. ${ }^{1} \mathrm{H}$ NMR spectrum of 1 recorded in $\mathrm{CDCl}_{3}$. 


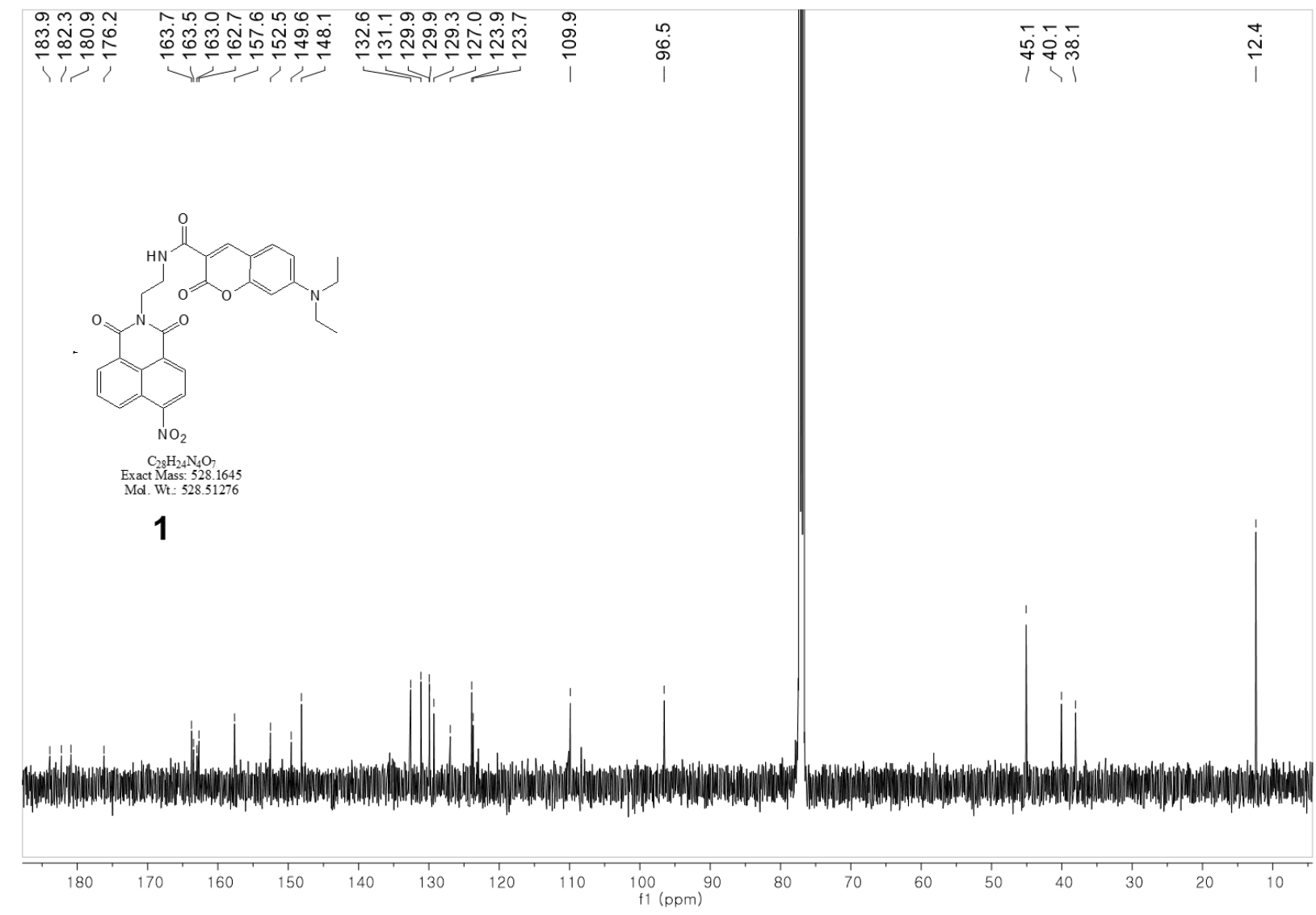

Figure S13. ${ }^{13} \mathrm{C}$ NMR spectrum of 1 recorded in $\mathrm{CDCl}_{3}$.

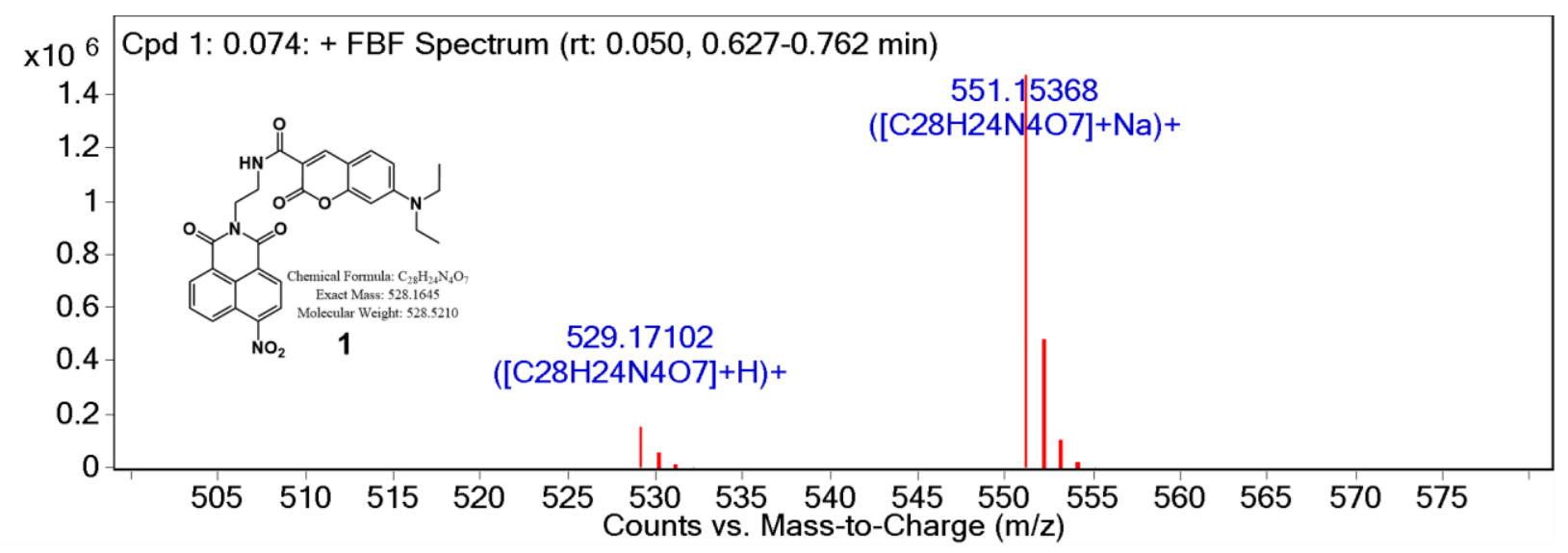

Figure S14. HR-ESI-MS spectrum of 1. 


\section{Reference}

1. Oushiki, D.; Kojima, H.; Terai, T.; Arita, M.; Hanaoka, K.; Urano, Y.; Nagano, T. Development and application of a near-infrared fluorescence probe for oxidative stress based on differential reactivity of linked cyanine dyes. J. Am. Chem. Soc. 201 0, 132, 2795-2801. 